\title{
The Plant Species Diversity of Lasitae Protected Nature Forest and Nearby Area, District of Barru, South Sulawesi
}

\author{
Rismita Sari1*, Fauziah ${ }^{2}$, Inggit Puji Astuti ${ }^{1}$, Ratna Susandarini ${ }^{3}$, Irwan Makmur ${ }^{4}$ \\ 1) Research Centre for Plant Conservation and Botanic Garden-Indonesian Institute of Sciences (LIPI), Jln. Ir. H. Juanda 13, Bogor \\ 16003, West Java, Indonesia \\ 2) Purwodadi Botanic Garden-Research Centre for Plant Conservation and Botanic Garden (LIPI), Jln. Surabaya-Malang Km 65, \\ Purwodadi-Pasuruan 67163, East Java, Indonesia \\ 3) Faculty of Biology, Gadjah Mada University, Bulak Sumur 55821, Yogyakarta, Indonesia \\ 4) Forest Management Unit (KPH) Ajatappareng, Forestry Service, South Sulawesi Province, Jln. Sultan Hasanuddin No. 95, Barru \\ District, South Sulawesi, Indonesia
}

Submitted: 28 January 2020; Accepted: 06 April 2020; Published: 15 August 2020

\begin{abstract}
An expedition to Lasitae Protected Forest in District of Barru, South Sulawesi was undertaken to collect living plants for Pucak Botanic Garden, South Sulawesi. The aims were to investigate the diversity of the plants and as a dedication to the Expedition of the Republic of Indonesia Corridor Sulawesi. Using an explorative method, we collected the plants and recorded all data in the field following the tracks assisted by the field guide. A total of 179 collection-numbers have been collected from this dry lowland forest including the data for the local names. Many potential and valuable plants occur in the forest, 13 plants were highlighted in this paper for its conservation status, the potentiality for various purposes or its uniqueness: Diospyros celebica Bakh. or streak ebony (Ebenaceae), Arenga pinnata (Wurmb.) Merr. (Arecaceae), Phyllanthus lamprophyllus Mull.Arg. (Phyllanthaceae), Cycas rumphii Miq. (Cycadaceae), Lagerstroemia speciosa (L.) Pers. (Lythraceae), Garcinia celebica L. (Clusiaceae), Nervilia aragoana Gaud. (Orchidaceae), Phalaenopsis amabilis (L.) Blume (Orchidaceae), Ophioglossum reticulatum L. (Ophioglossaceae), Tetracera scandens (L.) Merr. (Dilleniaceae), Derris trifoliata Lour., Phytocrene bracteata Wall. (Icacinaceae), and Dioscorea bispida Dennst. Buchanania arborescens (Blume) Blume and Ardisia elliptica Thunb. can easily be found and widely spread.
\end{abstract}

Keywords: plant species diversity, protected forest, rare plants

\section{INTRODUCTION}

Indonesia is one of the 17 megadiverse countries in the world that has ca. 37,000 plants species, the third rank after Brazil and Colombia (Paknia, Rajaesh \& Koh, 2015). Among the five biggest islands in Indonesia, Sulawesi is well-known for its richness on biodiversity and endemicity (Widjaja \& Pratama, 2013). In a study in Lore Lindu National Park, Central Sulawesi, it was found that the endemicity reaching ca. 15\% of trees (Gradstein et al., 2007). Its position between the Wallace line and Weber line supports its high diversity of flora and fauna among other islands in Indonesia.

One of the protected forests in Sulawesi is Lasitae Protected Forest (Hutan Lindung Lasitae)

\section{*Corresponding author}

Email: mita_krb@yahoo.com

(C) 2020, J. Tropical Biodiversity Biotechnology (CC BY-SA 4.0) which is located in the District of Barru, South Sulawesi. The District of Barru is situated up north of Makassar city and stretches along the west coast. The Lasitae Protected Forest (PF) is located $10 \mathrm{~km}$ from the main city of Barru and covers 49.801 ha $\mathrm{km} 2$ areas. (Dinas Kehutanan Kabupaten Barru, 2005).

The flora of Lasitae PF has never been investigated previously, therefore the South Sulawesi Province Government recommended this location to our expedition team. This expedition was carried out to support the collection enhancement for Pucak Botanic Garden (BG) which is located in the District of Maros, South Sulawesi. The Pucak BG is under the management of the South Sulawesi Province Government. The Bogor Botanic Garden has been assisting the establishment of the Pucak BG since 2006. The plants collected in this expedition would 
be submitted as the living collection for the Pucak BG. This expedition was also dedicated to the Expedition of the Republic of Indonesia Corridor Sulawesi (Ekespedisi NKRI Koridor Sulawesi) which was organized by the Indonesian Army Special Forces group (Kopassus).

\section{Aims}

This expedition aimed to identify the plant species diversity of Lasitae PF, to unveil the unique and potential flora of Lasitae PF and targeted to collect 125 collection numbers for the Pucak BG. The number of the target is the average number that usually can be collected based on the annual expedition of Bogor Botanic Garden.

\section{MATERIALS AND METHODS}

\section{Material}

The material we collected were the plants in Lasitae PF, Padang Loang Community Based Forest (Hutan Rakyat Padang Loang), Coppo Village \& Lipukasi Village, District of Barru.

The equipment we used were the standard expedition equipment package supplied by Bogor Botanic Garden contains small $(10 \times 15 \mathrm{~cm})$ and medium $(25 \times 30 \mathrm{~cm})$ size black plastic bags, multi sizes clear plastic bags, plastic sacks, yellow tags for living collection, paper tags for herbarium specimens, clip plastic bags for $0,5 \mathrm{~kg}$ and $0,25 \mathrm{~kg}$, Rootone-F (PT. Rhone-Poulenc Agrocarb, Surabaya, Indonesia), Dithane M-45 (PT. Dow AgroSciences Indonesia, Medan, Indonesia), alcohol 70\%, rolled tissue, used newspaper, shade fabric, polybag, ruler $30 \mathrm{~cm}$, plastic rope, rubber bands, sticky tapes, and cardboard boxes for packing.

Tools we used were altimeter, thermo hygrometer, GPS (Garmin), cutters, scissors, secateurs, machetes, two types of digital camera, field books and stationaries.

\section{Method}

The expedition was carried out by an explorative method. The location was determined by the local guides Mr. Irwan Makmur and Mr. Suriadi. We provided a list of the plants we targeted but other plants that we considered were necessary to be collected would also be taken. The timetable for the activities from 27 May-3 June 2013 was made to reach the maximum outcome.

We walked along the track from the Copo Village through Padang Loang Community Based Forest until the border of Lasitae PF for about 400 $\mathrm{m}$. All the plants we collected were documented and labeled while temperature and ecological data were noted. The first day we walked along the track where the villagers used to take their cows to the forest. The last day we walked along the main road that connects the villages.

All the plants collected were sampled for herbarium vouchers and deposited in Bogor Botanic Garden. The herbarium specimens were labeled completed with the name of the species, family, collector's number, the date of collecting and the location. The same label was tagged to the living collection.

\section{RESULTS AND DISCUSSION}

\section{Results}

A total of 179 collection numbers were successfully collected in this expedition. Each collection number has one or more plants, seeds, or seedlings for the stock if it could not survive in the nursery of Pucak BG. It covered 59 families but only 83 collection numbers have successfully identified (Table 1). The rest were 89 collection numbers have been recognized up to the genus level and 8 collection numbers were only recognized up to family level (Table 2). All plants were collected from four locations as mentioned in the Material section, but the main collection and the most number collections were from Lasitae PF. Some species were collected more than once when we found in different locations as it was considered from different populations that genetic variation might occur.

A few plants were bearing fruits such as Garcinia celebica L. (Clusiaceae), Buchanania arborescens (Blume) Blume (Anacardiaceae), Ardisia elliptica Thunb. (Myrsinaceae), Acronychia vetandra (F. Muell.) T.G. Hartley (Rutaceae), Cycas rumphii Miq. (Cycadaeae) and Derris trifoliata Lour. (Fabaceae). Some other plants were still flowering such as Dendrobium sp. (Orchidaceae) and Tetracera scandens L. (Dilleniaceae).

The altitude range we explored was from 33 $159 \mathrm{~m}$ above sea level (asl). The daily temperature during this expedition was between $23-36^{\circ} \mathrm{C}$, with relative humidity (RH) ranged between $49-84 \%$. The soil is rocky with $\mathrm{pH}$ ranges from 5.7-6.8 and the soil RH $50-100 \%$. The forest type is a typical lowland rain forest.

This forest is the water source for the villagers, supplied by the Padalampe river inside the forest. The river was small with clear water but shallow. The river flows along the rocks giving humidity to the surrounding support the plants with water supplies. There were many plants grew along the riverside. We selected Dioscorea bispida Dennst. (Dioscoreaceae), Tacca palmata Blume. (Taccaceae), Tabernaemontana sp. (Apocynaceae), Alocasia alba Schott. (Araceae), Garcinia xanthochymus (Roxb), Kurz 
(Clusiaceae), Piper sp. (Piperaceae), Daemonorops sp. (Arecaceae), Cinnamomum sp. (Lauraceae) and Cymbidium finlaysonianum Lindl. (Orchidaceae), Pandanus sp. (Pandanaceae), Hoya sp. (Asclepiadaceae) and Pleomele sp. (Agavaceae) to be collected.

A bit deeper in the forest, there was the sugar palm, Arenga pinnata (Wurmb) Merr. (Arecaceae). People collected nira or sweet palm juice from the sugar palm for making palm sugar. There were also streak ebony populations that occur (Diospyros celebica Bakh., Ebenaceae) in the forest that was highly protected by the local government as this taxon is a rare endemic tree (World Conservation Monitoring Centre, 1997). There were two populations of streak ebony in this forest, which the bigger population contained 15 mature trees while the other has four mature trees. The seedlings were abundant around the mature trees.

\section{Discussion}

The result of this expedition has demonstrated that Padang Loang Community Based Forest and Lasitae $\mathrm{PF}$ has a high plant diversity. The 59 families that occur in this forest including the endemic species of streak ebony indicated that this location represents the typical lowland tropical forest of Sulawesi. The plants we collected ranged from ferns to Gymnosperms and Angiosperms have potentiality in different purposes as the previous studies reported. The forest was still dense and mostly in good condition. The total collection numbers we obtained were more than our target and it showed that this forest contains lots of varieties of plants that should be protected from any disturbance.

As this forest is very close from the west coast the weather is hot and the forest tends to be dry with a little source of water. According to the Pemerintah Kabupaten Barru (2013), the soil type in the District of Barru is regosol with medium fertile type. The soil is basically volcanic which is spread all over the district. In the area, we explored the soil is very rocky that makes the soil is relatively hard. In a few sites, the land composed of rocks particularly in Padang Loang Community Based Forest. The rocks in the palm-size were scattered on the ground in a relatively wide area (Figure 1). However, the richness of plant diversity in the forest is remarkably sustained in this type of soil.

Among the plants we collected, there are a few valuable plants based on the economic values, usages or conservation status. We would like to highlight 13 plants in this paper that we considered distinct among other plants. The first one we would like to focus on is Diospyros celebica or streak ebony. This plant is one of the most valuable plants in this forest.
The massive harvesting of the wood across Sulawesi for years causing the population has been decreasing (Riswan, 2002; Walujo, 2002). This plant is now categorized as Vulnerable (VU) according to the IUCN Red List (World Conservation Monitoring Centre, 1998). The presence of streak ebony in this conservation area was well protected as indicated by the oldest tree still exists (Figure 2).

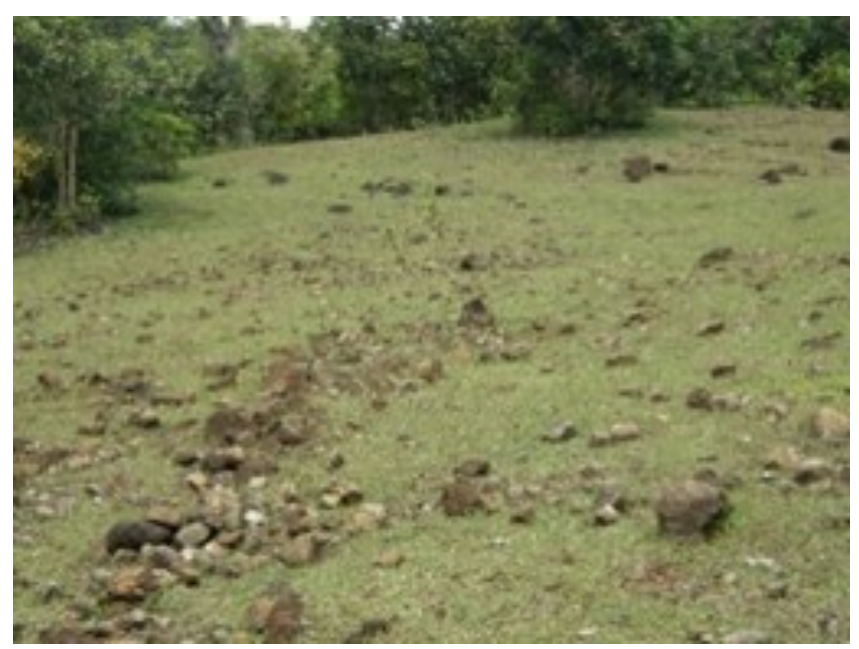

Figure 1. Padang Loang Community Based Forest (Photograph: Rismita Sari).

The sugar palm Arenga pinnata is well-known as a multipurpose palm (Mogea et al., 1991). This palm distributed widely in SE Asia including Indonesia. The main yield of this palm is the palm sugar that processed from the sweet juice collected from the stalk of the flower. The juice is usually collected daily to avoid fermentation. Other usages are the flesh of the fruits known as kolang-kaling and the black fibers resulted from the sheath can be used for many household purposes. To obtain the juice or the fruits traditionally people have to climb the tree as the flower and fruit are on the top of the tree (Figure 3). The people in Lasitae PF leave a bamboo ladder on the tree to make them easier to collect the juice that was accumulated in a tin.

The small plants we collected in Padang Loang Community Based Forest, Phyllanthus lampropbyllus Mull.Arg. (Phyllanthaceae) (Figure 4) is one of 13 Phyllanthus species that have been found in Sulawesi (Bouman et al., 2019). It grows widely in Padang Loang. This plant occurs in Java, Lesser Sunda Island, New Guinea, the Philippines, Queensland (Australia) and Sulawesi (Govaerts, 2000). The plant has not been used by the local people and easy to find in the Padang Loang. The plant itself might be able to be used as an ornamental plant as it has beautiful leaves arrangement and colour.

A Gympospermae plant, Cycas rumphii, grows well in the Padang Loang Community Based Forest and Lasitae PF (Figure 5). This cycad has been used 
as an ornamental plant and a very common plant in the gardens in SE Asia. In fact, the seed has been known is acutely toxic after a case of Chamorro people who used the flour from the fruits in their cuisine has digestions problems (Cox \& Sacks, 2002). According to the IUCN Red List, the category of conservation status of $C$. rumphii is Near Threatened (NT) as the population is decreasing in the wild (Hill, 2010).

Lagerstroemia speciosa (L.) Pers. (Lythraceae) was found at Padang Loang Village. The flowering season has passed leaving dry split fruits on the tree (Figure 6). This plant is a common roadside tree in SE Asian countries. The beautiful flower and the shady canopy have made this tree very popular. Besides as an ornamental tree, people in the Philippines use the plant to cure diabetic and kidney problems (Klein et al., 2007). This tree is known contains active chemical compounds that cure some diseases.

There are a few edible fruit plants in the Lasitae PF. At least there are two genera produce fruits, Garcinia spp. and Mangifera spp. One of the taxa, G. celebica L. (Clusiaceae) is known as edible fruits by the locals (Figure 7). The fruits were at a very young stage when we found it, so we were not able to taste the fruits. Compared with the G. celebica collection in Bogor Botanic Garden-LIPI, the fruits were smaller. The size of G. celebica in the Bogor BG ranges between 3-4 cm in diameter. The G. celebica in Lasitae PF was ca. $3 \mathrm{~cm}$ in diameter. Garcinia has many variations in the wild. The variations range from size, colour, and taste as well.

The orchids in the forest vary from terrestrial to epiphyte while most of them were epiphytes. One of the terrestrial orchids was Nervilia aragoana Gaudich. (Orchidaceae) (Figure 8). It was found in the open forest near Lipukasi Village and it is common in the Lasitae forest but a bit rare in other areas in Indonesia. The orchid is unused by the locals, whereas in Taiwan, N. aragoana has been used as herbal medicine to heal a few diseases (Kikuchi et al., 1981).

The existence of rare orchid Phalaenopsis amabilis (L.) Blume (Orchidaceae) was an indication that Lasitae PF is very rich with plant diversity. The orchid P. amabilis is one of the very popular orchids and became rare in the wild after excessive harvesting for its beautiful flower including deforestation, commercial trades, illegal logging, land conversion and domestication of native orchids (Semiarti, 2002). It has been well domesticated and cross-pollinated resulting in various hybrids. We only found one individual plant that had an empty peduncle as an indication that the flowering season is over (Figure 9).
The fern Ophioglossum reticulatum L. (Ophioglossaceae) is a small fern that occurs in Lasitae PF (Figure 10). The population was found growing in a relatively open area near Lippukasi Village. This fern is also called the adder's-tongue fern that according to IUCN Red List the conservation status is LC (Least Concern) (Irudayaraj, 2011). The genus of this single leaf fern contains 25-30 species that widely distributed in the temperate and the tropics area. This fern has been known to have antimicrobial compounds (Mukherjee et al., 2017).

A woody climber, Tetracera scandens was in full bloom when we found it at the roadside of the main road to the Lasitae PF (Figure 11a). This plant grows widely in India, China, Indonesia, Myanmar, Philippines, Thailand, Malaysia, and Vietnam (Thanh et al., 2015; Muliyah et al., 2017). The trunk can be used as a source of drinkable water if it is unavailable in the forest. The water in the trunk can be accumulated by cutting the trunk and it will pour out from the surface of the cut (Figure 11b). The leaves can be used as a sandpaper to smooth the machete handle as it has coarse surface as shown by our field guide.

Another plant that contains drinkable water is Derris trifoliata. This woody climber can be recognized in the wild from the fruits (Figure 12a \& b). It is widely spread in the world particularly in the tropics (Roskov et al., 2020). In Lasitae PF, D. trifoliata grows near the small river near the Lipukasi Village. The trunk climbs the other trees across the river. Despite $D$. trifoliata contains various chemical substances in the parts of the plant (Wenjie et al., 2009; Mamoon \& Azam, 2012) our field guide, Mr. Suriadi showed it is safe to drink the water from the trunk (Figure 12c).

Phytocrene bracteata Wall. (Icacinaceae) is a woody climber that occurs in Lasitae PF. We found the flowers at the early stage (Figure 13). The P. bracteata in Sulawesi has been previously reported found in the karst hills valley in the south of Sulawesi (Saiful \& Burhan, 2017). The most interesting thing about this plant is the fruits. Despite it is not edible, but the shape is distinct.

Dioscorea hispida is one of the plants that produce carbohydrates and has been used as a food source after treated using some techniques to remove cyanides and other poisonous chemical substances (Kumoro et al., 2011). The starchy yam can be made into chips or other food like biscuits. We found a tuber of $D$. hispida on the location from one plant. The size of the tuber is ca. $15 \mathrm{~cm}$ in diameter with $8 \mathrm{~cm}$ thick (Figure 14). There was only one population of D. hispida along the river. The trunk has rare leaves indicating it is an old plant. 
Dioscorea is a climber and usually grows easily. The small population of this plant might be influenced by the climate or soil condition that has less support for the plant to regenerate.

There are many more plants in this forest that can be explored for its potentiality. This lowland forest has shown its diversity and many potential plants grow there. It is recommended to explore further into the other parts of the forest to find more information about the plants in this protective area.

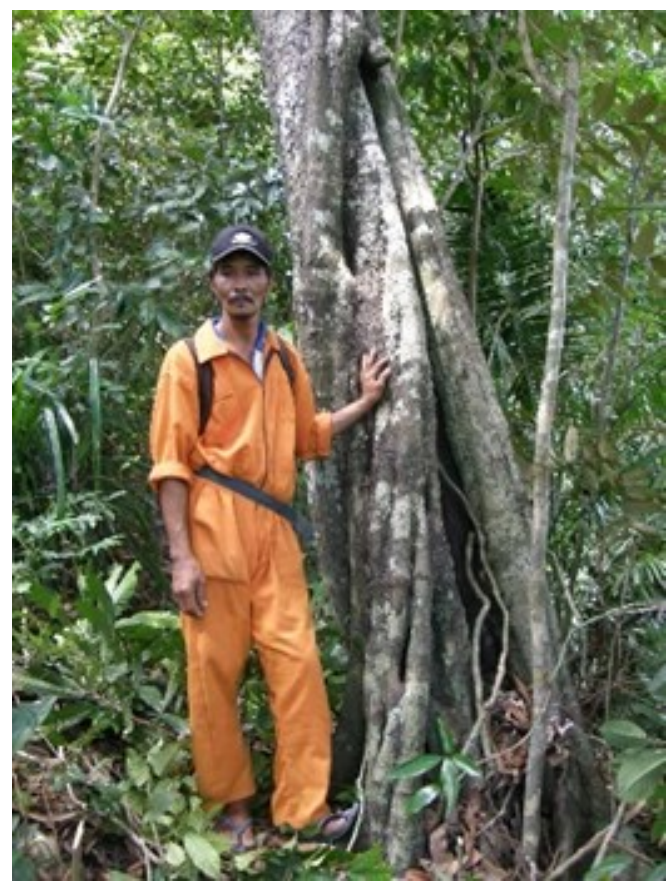

Figure 2. The oldest streak ebony (Diospyros celebica Bakh.) in Lasitae PF with Mr. Suriadi (Photograph: Rismita Sari).

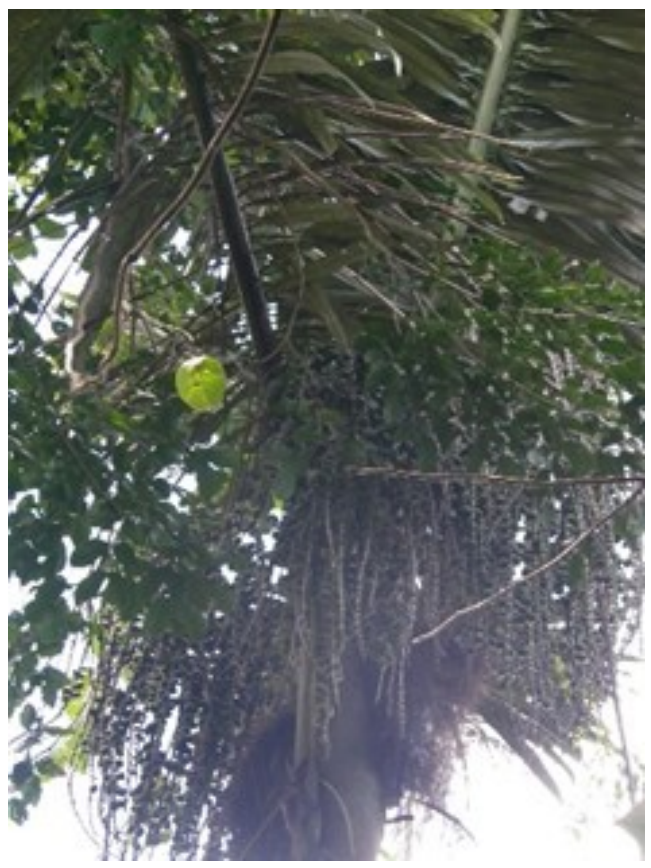

Figure 3. Arenga pinnata (Wurmb) Merr. (Photograph: Rismita Sari)

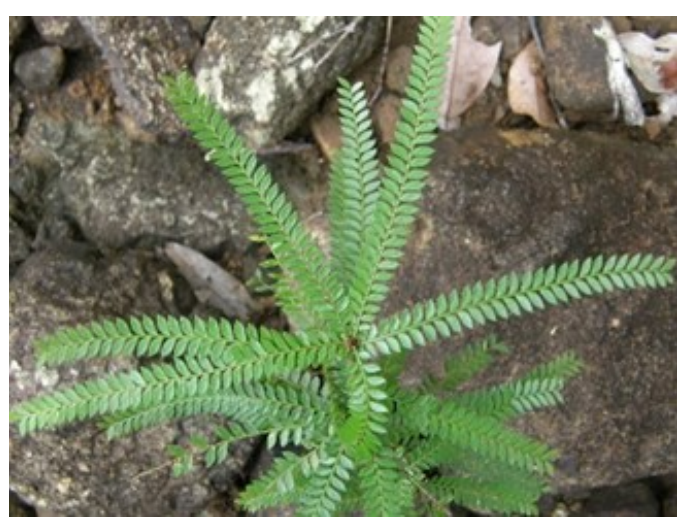

Figure 4. Phyllanthus lamprophyllus Mull.Arg. (Photograph: Rismita Sari).

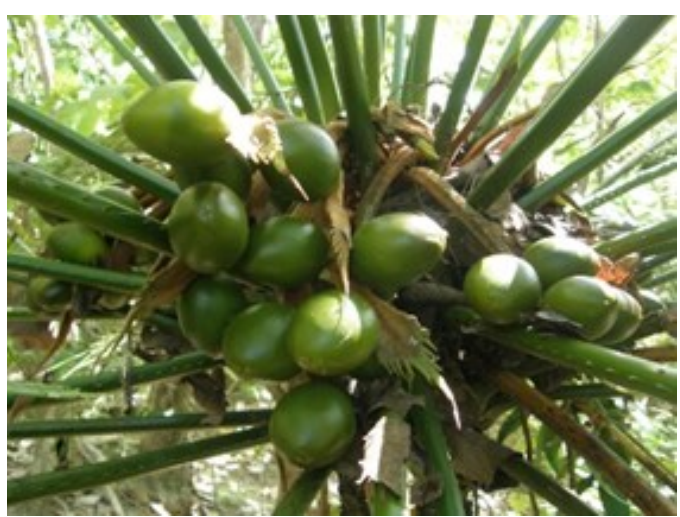

Figure 5. Cycas rumphii Miq. (Photograph: Rismita Sari).

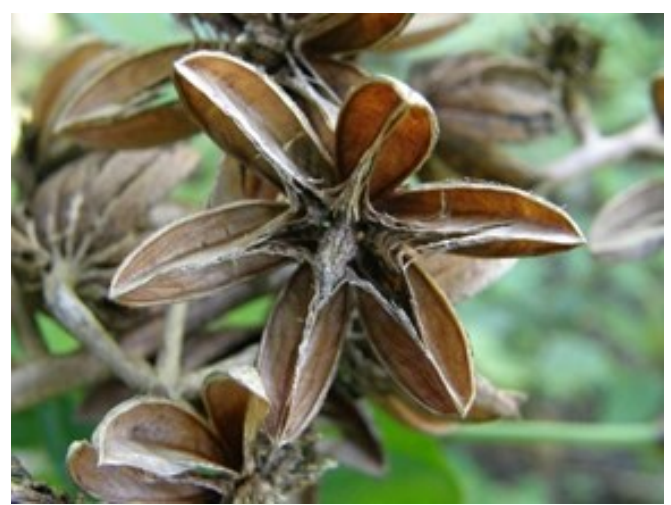

Figure 6. Dry fruits of Lagerstroemia speciosa (L.) Pers. (Photograph: Rismita Sari).

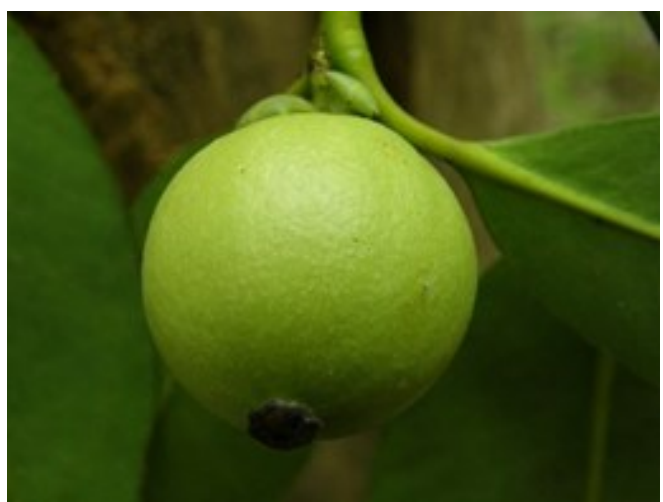

Figure 7. Young fruit of G. celebica L. (Photograph: Rismita Sari). 


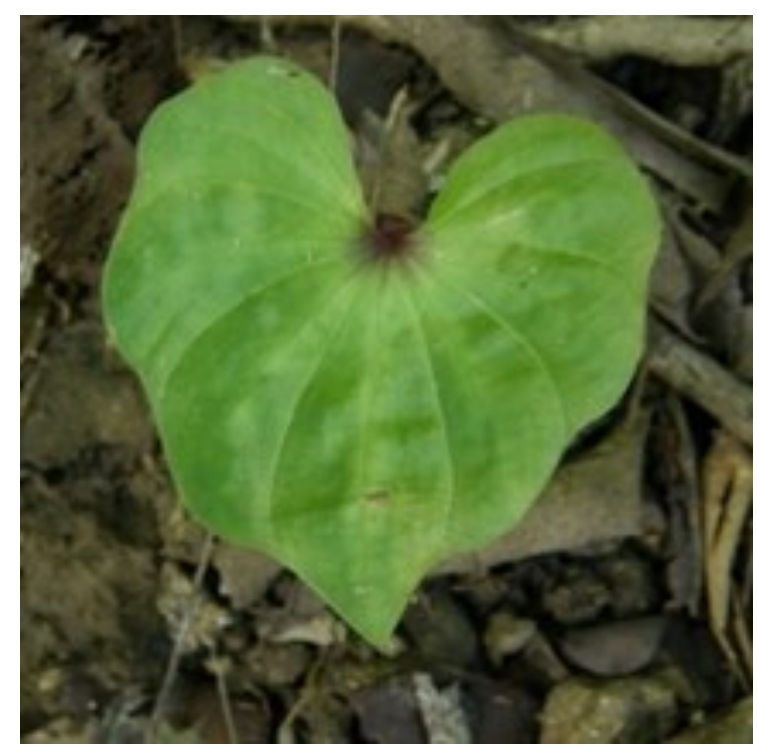

Figure 8. Nervilia aragoana Gaudich. (Photograph: Rismita Sari).

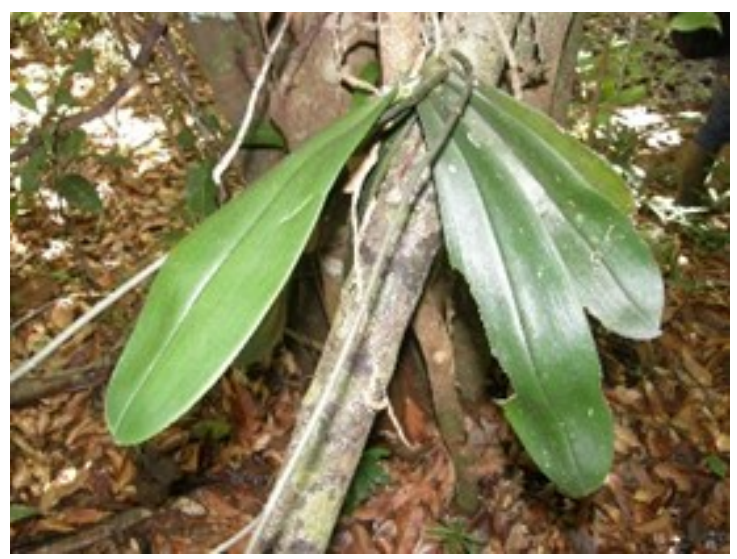

Figure 9. Phalaenopsis amabilis (L.) Blume (Photograph: Rismita Sari).

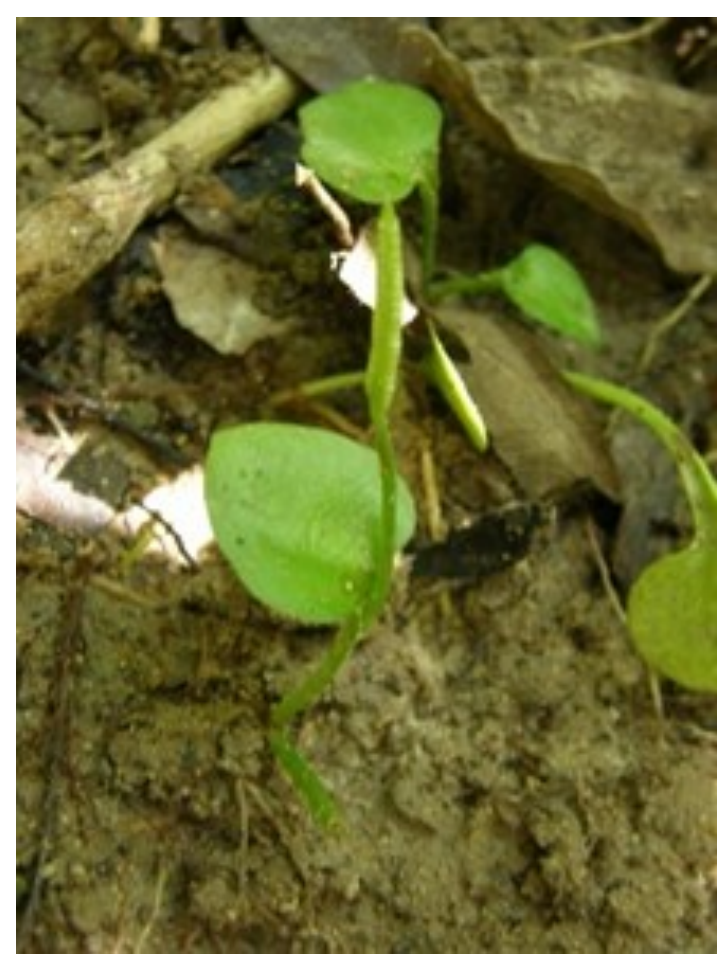

Figure 10. Ophioglossum reticulatum L. (Photograph: Rismita Sari)

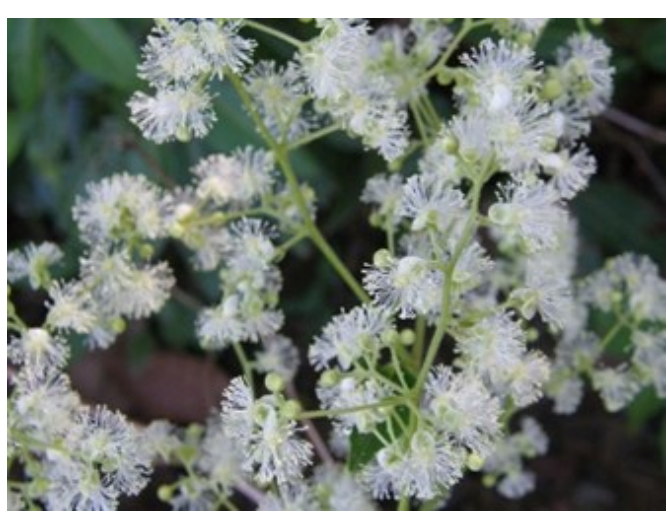

(11a)

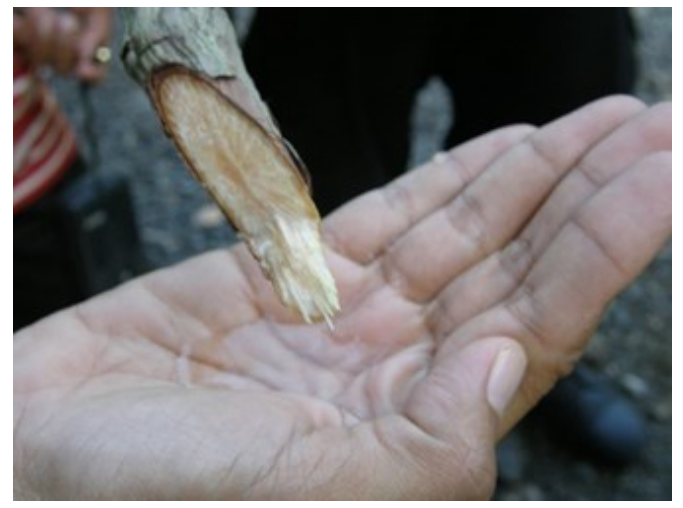

(11b)

Figure 11. Flower of Tetracera scandens (L.) Gilg \& Werderm. (a). The water from the trunk of T. scandens (b) (Photographs: Rismita Sari).

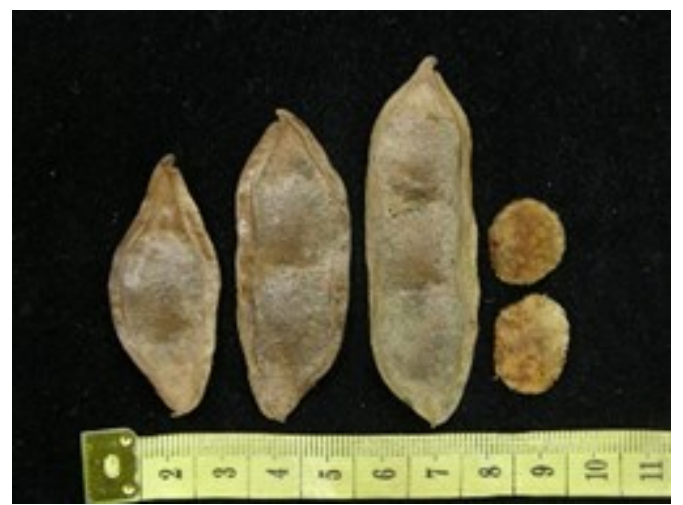

(12a)

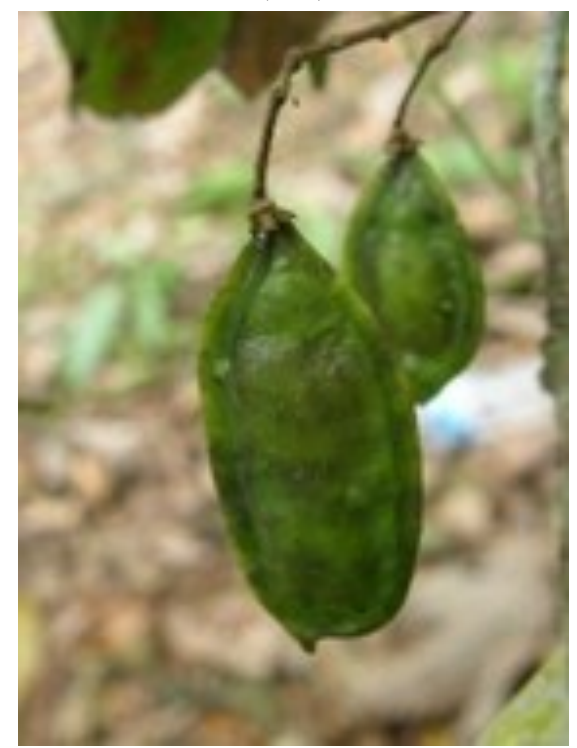

(12b) 


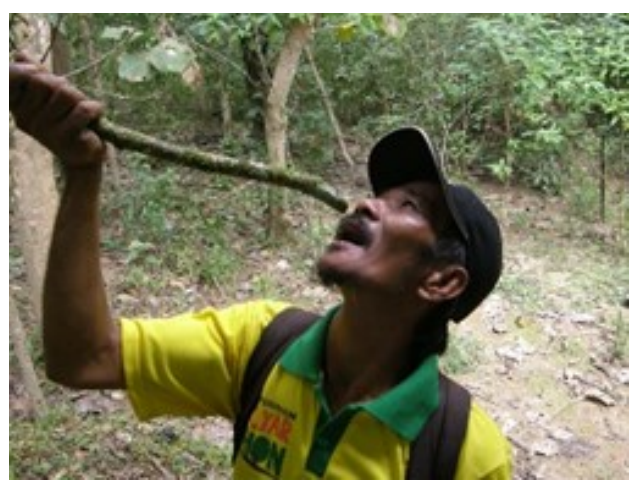

(12c)

Figure 12. Dry fruits of Derris trifoliata Lour. (a); Young fruits of D. trifoliata (b); Mr. Suriadi is showing how to drink the fresh water from the trunk of D. trifoliata (c). (Photographs: Rismita Sari)

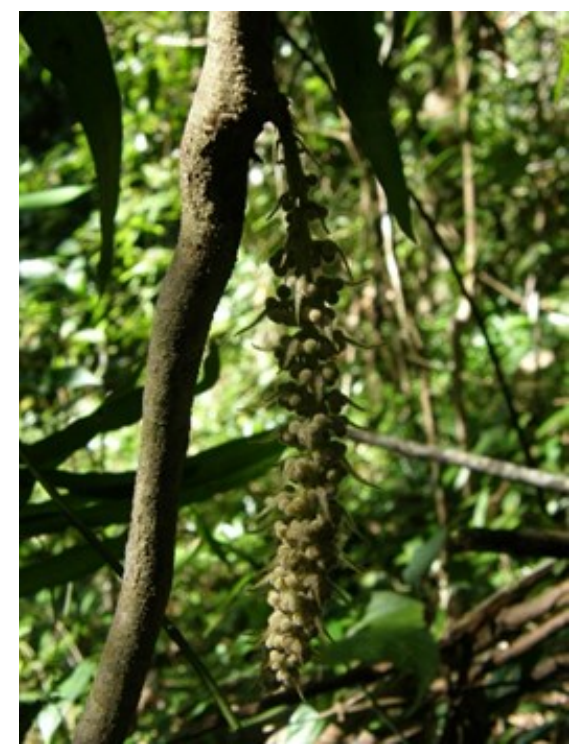

Figure 13. The flower buds of Pbytocrene bracteata Wall. (Photograph: Rismita Sari)

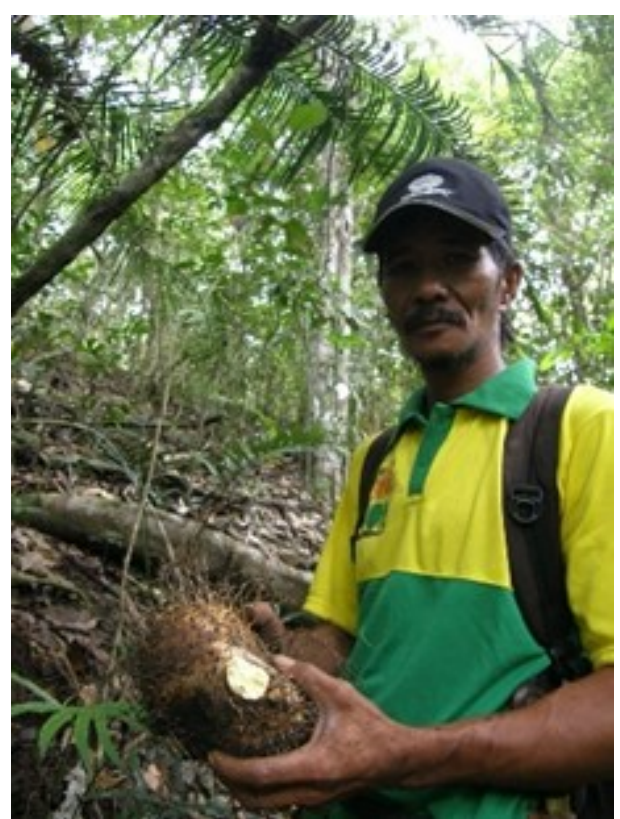

Figure 14. The tuber of Dioscorea hispida Dennst. is held by Mr. Suriadi. (Photograph: Rismita Sari)

\section{CONCLUSION}

The Lasitae PF and the surrounding area is an important forest as it plays an important role in supporting the locals' life such as supplies water source, food, wild fruits, ornamental plants, and other usages including rare plants. It is very important to keep the forest protected, as it contains many useful plants for various purposes. Moreover, there are many plants in this forest that contains phytochemical substances that might be developed in the future. The sustainability of this forest should be maintained for the advantages of the people around the forest and to benefit people in the future.

Table 1. The species that have been identified.

\begin{tabular}{|c|c|c|c|}
\hline No. & Species & Family & Local names \\
\hline 1. & Acronychia vetandra (F. Muell.) T.G. Hartley & Rutaceae & matte-matte komba' \\
\hline 2. & Aerides odorata Lour. & Orchidaceae & - \\
\hline 3. & A. odorata & Orchidaceae & - \\
\hline 4. & A. odorata & Orchidaceae & - \\
\hline 5. & A. odorata & Orchidaceae & - \\
\hline 6. & Aglaonema modestum Schott ex Engler & Araceae & - \\
\hline 7. & Alocasia alba Schott. & Araceae & lawira \\
\hline 8. & A. alba & Araceae & - \\
\hline 9. & Amorphophallus paeoniifolius (Dennst.) Nicolson & Araceae & bote \\
\hline 10. & Ardisia elliptica Thunb. & Myrsinaceae & bineppu \\
\hline 11. & Arenga pinnata(Wurmb.) Merr. & Arecaceae & aren \\
\hline 12. & A. pinnata & Arecaceae & - \\
\hline 13. & Brucea javanica (1.) Merr. & Simarubaceae & tampak \\
\hline 14. & Buchanania arborescens Blume & Anacardiaceae & pawale' \\
\hline 15. & Bulbophyllum lepidum (Blume) J.J.Smith & Orchidaceae & - \\
\hline 16. & Cananga odorata (Lam.) Hook.f.\&Thomson & Annonaceae & kenanga \\
\hline 17. & C. odorata & Annonaceae & kananga \\
\hline 18. & Cephaelis ipecachuanba (Brot.) A.Rich. & Rubiaceae & - \\
\hline 19. & Clausena indica (Dalzell.) Oliv. & Rutaceae & - \\
\hline 20. & Clerodendrum minahassae Teisjm. \& Binn & Boraginaceae & lalik-lalik manuk \\
\hline
\end{tabular}


Table 1. Contd.

\begin{tabular}{|c|c|c|c|}
\hline No. & Species & Family & Local names \\
\hline 21. & Crinum asiaticum $\mathrm{L}$. & Amaryllidaceae & peno'-peno' \\
\hline 22. & Cyathea latebrosa (Wall. ex Hook.) Copel. & Cyatheaceae & - \\
\hline 23. & Cyathula prostrata (I.) Blume & Amaranthaceae & pale' anyarang, tapal kuda \\
\hline 24. & Cycas rumphii Miq. & Cycadaceae & pattoku \\
\hline 25. & Cymbidium finlaysonianum Lindl. & Orchidaceae & - \\
\hline 26. & Cynometra ramiflora $\mathrm{L}$. & Fabaceae & lambe-lambe \\
\hline 27. & Dendrobium anosmum Lindl. & Orchidaceae & - \\
\hline 28. & Dendrobium juncifolium Schltr. & Orchidaceae & \\
\hline 29. & D. juncifolium & Orchidaceae & - \\
\hline 30. & Derris trifoliata Lour. & Fabaceae & lacciran \\
\hline 31. & Dillenia ochreata (Miq.) Teisjm. \& Binn. ex Mart. & Dilleniaceae & lakonra \\
\hline 32. & Dioscorea hispida Dennst. & Dioscoreaceae & siapa \\
\hline 33. & Diospyros celebica Bakh. & Ebenaceae & amara \\
\hline 34. & D. celebica & Ebenaceae & amara \\
\hline 35. & Donax canniformis (G. Forst.) K.Schum & Marantaceae & bampeng bunga \\
\hline 36. & D. canniformis & Marantaceae & bampeng \\
\hline 37. & Ehretia timoriensis Decne & Boraginaceae & - \\
\hline 38. & Elephantopus spicatus Aubl. & Asteraceae & kasalla’ \\
\hline 39. & Garcinia celebica $\mathrm{L}$. & Clusiaceae & tire \\
\hline 40. & G. celebica & Clusiaceae & tire \\
\hline 41. & G. dulcis (Roxb.) Kurz & Clusiaceae & tire \\
\hline 42. & G. xanthochymus Hook.f. ex T.Anderson & Clusiaceae & - \\
\hline 43. & Hoya revoluta Wight. & Asclepiadaceae & doi'-doi' \\
\hline 44. & Hypobathrum multibracteatum Elmer & Rubiaceae & - \\
\hline 45. & Knema celebica (Poir.) Warb. var. cinerea & Myristicaceae & kuerempang \\
\hline 46. & Lagerstroemia speciosa (L.) Pers. & Lytheraceae & allouting \\
\hline 47. & Leea asiatica (L.) Ridsdale & Leeaceae & arunganga \\
\hline 48. & L. rubra Blume ex Spreng & Leeaceae & mali-mali \\
\hline 49. & Lepisanthes rubiginosa (Roxb.) Leenh. & Sapindaceae & jampu nono \\
\hline 50. & Luisia taurina J.J.Sm. & Orchidaceae & - \\
\hline 51. & Lygodium circinnatum (Burm.f.) Sw. & Schizaeaceae & cawe \\
\hline 52. & Magnolia candollii (Blume) H. King var. candollii & Annonaceae & sarikajaale \\
\hline 53. & Malaxis blumei Bakh.f. & Orchidaceae & pije'-pije' \\
\hline 54. & Mallotus floribundus (Blume) Mull.Arg. & Malvaceae & waru-waru \\
\hline 55. & Mangifera indica $\mathrm{L}$. & Anacardiaceae & pao cucok \\
\hline 56. & M. indica & Anacardiaceae & pao kurisa' \\
\hline 57. & Mucuna pruriens L. & Papilionaceae & awiyu \\
\hline 58. & Nephrolepis cordifolia (L.) Pr. & Davalliaceae & - \\
\hline 59. & Nervilia aragoana Gaudich. & Orchidaceae & - \\
\hline 60. & N. aragoana & Orchidaceae & - \\
\hline 61. & N. aragoana & Orchidaceae & - \\
\hline 62. & Ophioglossum reticulatum $\mathrm{L}$. & Ophioglossaceae & tungke'-tungke' \\
\hline 63. & Pandanus tectorius Parkinson ex Du Roi & Pandanaceae & - \\
\hline 64. & Phalaenopsis amabilis (L.) Blume & Orchidaceae & - \\
\hline 65. & Phytocrene bracteata Wall. & Icacinaceae & - \\
\hline 66. & Piper amboinense C.DC. & Piperaceae & ganjing tedong \\
\hline 67. & P. caninum Blume & Piperaceae & - \\
\hline 68. & P. flavimarginatum C.DC. & Piperaceae & - \\
\hline 69. & Planchonia valida (Blume) Blume & Lecythidaceae & alakkan \\
\hline 70. & Psychotria celebica $\mathrm{L}$. & Rubiaceae & kopi ale' \\
\hline
\end{tabular}


Table 1. Contd.

\begin{tabular}{clll}
\hline No. & \multicolumn{1}{c}{ Species } & \multicolumn{1}{c}{ Family } & \multicolumn{1}{c}{ Local names } \\
\hline 71. & Pterospermum celebicum Miq. & Sterculiaceae & wajo' \\
72. & Pyllanthus lamprophyllus Mull.Arg. & Euphorbiaceae & cempa-cempa \\
73. & Sandoricum koetjape (Burm.f.) Merr. & Meliaceae & - \\
74. & Sesuvium portulacastrum (L.) L. & Aizoaceae & - \\
75. & Stemona moluccana (Blume) C.H. Wright & Stemonaceae & - \\
76. & Sterculia foetida L. & Sterculiaceae & bimpi \\
77. & Syzigium aqueum (Burm.f.) Alston & Myrtaceae & jampu-jampu salo’ \\
78. & Tabernaemontana celebica Miq. & Apocynaceae & lambuto \\
79. & Tacca palmata Blume & Taccaceae & - \\
80. & Tectaria shabidaniana Rusea & Aspidiaceae & warang parang \\
81. & Tetracera scandens (L.) Merr. & Dilleniaceae & apelle’ \\
82. & Thrixspermum mus S. Rao & Orchidaceae & - \\
83. & Vittaria flexuosa Fee & Aspidiaceae & - \\
\hline
\end{tabular}

Table 2. The plant families, unidentified species collected and local names.

\begin{tabular}{|c|c|c|}
\hline No & Family & Species \& Local names \\
\hline 1. & Acanthaceae & Acanthus sp. \\
\hline 2. & Actinidiaceae & Saurania sp. \\
\hline 3. & Adiantaceae & Adiantum sp. \\
\hline 4. & Agavaceae & Pleomele sp. (jalojo) \\
\hline 5. & Annonaceae & $\begin{array}{l}\text { Desmos sp.1 (loka-loka), Desmos sp.2, Polyalthia sp.1 (kayu awayu), Polyalthia sp.2, Polyalthia } \\
\text { sp. 3, Trigonostemon sp. (tabo) }\end{array}$ \\
\hline 6. & Apocynaceae & Alstonia sp. (tiro tarik), Tabernaemontana sp., Stropanthus sp., Apocynaceae (damak-damak) \\
\hline 7. & Araceae & $\begin{array}{l}\text { Alocasia sp.1 (lawira), Alocasia sp.2 (aladi), Alocasia sp.4, Colocasia sp.1, Colocasia sp.2, Phy- } \\
\text { lodendron sp., Pothos sp.1 (banga-banga), Pothos sp.2 }\end{array}$ \\
\hline 8. & Araliaceae & Aralia sp. (pallong-pallong) \\
\hline 9. & Arecaceae & Daemonorops sp.1 (rokan), Daemonorops sp.2 (anak rokan), Licuala sp. (talitta) \\
\hline 10. & Asclepiadaceae & Dischidia sp. (sikeppo), Hoya sp.1 (sikeppo) \\
\hline 11. & Burseraceae & Canarium sp. (lao bawi') \\
\hline 12. & Celastraceae & Maitenus sp. \\
\hline 13. & Clusiaceae & $\begin{array}{l}\text { Calophyllum sp. (betao), Cratoxylum sp. (geleng keleng), Garcinia sp.1 (tire), Garcinia sp.2 } \\
\text { (pakkeci anak lolo), Garcinia sp.3 (pakkeci anak lolo), Garcinia sp.4 (pakkeci anak lolo) }\end{array}$ \\
\hline 14. & Ebenaceae & Diospyros sp. (amara coppo) \\
\hline 15. & Euphorbiaceae & Euphorbiaceae (kaluku-kaluku) \\
\hline 16. & Fabaceae & $\begin{array}{l}\text { Abrus sp., Desmodium sp., Hymnaea sp. (kayu bayang), Peltophorum sp., Pterocarpus sp.1, } \\
\text { (calaipi), Pterocarpus sp.2 (cenrana), Fabaceae1 (warneng), Fabaceae2 (kayu langi) }\end{array}$ \\
\hline 17. & Flacourtiaceae & Flacourtia sp. \\
\hline 18. & Lauraceae & Cinnamomum sp. (alinie'), Litsea sp.1 (kayu kunyik-kunyik), Litsea sp.2 (rela-rela) \\
\hline 19. & Lecythidaceae & Cydaenanthus sp. \\
\hline 20. & Lytheraceae & Lagerstroemia sp.1 (geleng keleng), Lagerstroemia sp.2 \\
\hline 21. & Marantaceae & Donax sp.1 (bampeng) \\
\hline 22. & Meliaceae & Dysoxylum sp. (dare'-dare'), Aglaia sp. \\
\hline 23. & Moraceae & Artocarpus sp.1 (terou), Artocarpus sp.2 (kalompe), Artocarpus sp.3 (ampalang), Ficus sp. \\
\hline 24. & Myristicaceae & Knema sp.1 (kelam pelam, pala hutan), Myristica sp. (kayu buang) \\
\hline 25. & Myrtaceae & $\begin{array}{l}\text { Acmena sp., Syrigium sp.1 (jampu-jampu), Syzigium sp.2 (jampu-jampu), Syzigium sp.3, Syz- } \\
\text { igium sp.4 (mana'-mana'), Syzigium sp.5 (jampu-jampu), Syzigium sp.6 (tajulo) }\end{array}$ \\
\hline 26. & Orchidaceae & Calanthe sp. (pije'-pije'), Dendrobium sp., Habenaria sp., Trichoglottis sp. \\
\hline 27. & Pandanaceae & Pandanus sp. (banga) \\
\hline 28. & Piperaceae & Piper sp.1 (ganjing), Piper sp.2, Piper sp.3, Piper sp.4 \\
\hline 29. & Rhamnaceae & Ziziphus sp. (carrakak panning) \\
\hline 30. & Rubiaceae & Psychotria sp.2, Rubiaceae \\
\hline
\end{tabular}


Table 2. Contd.

\begin{tabular}{|c|c|c|}
\hline No & Family & Species \& Local names \\
\hline 31. & Rutaceae & $\begin{array}{l}\text { Citrus sp., Melicope sp.1 (matte-matte hutan), Melicope sp.2 (amara siapa), Rutaceae1 (matte- } \\
\text { matte), Rutaceae2 (tana-tana) }\end{array}$ \\
\hline 32. & Sapindaceae & $\begin{array}{l}\text { Euphoria sp. (jampu nono), Sapindaceae1 (lotong-lotong), Sapindaceae2, Sapindaceae3 } \\
\text { (kayu ori), Sapindaceae4 }\end{array}$ \\
\hline 33. & Schizaeaceae & Lygodium sp. (cawe) \\
\hline 34. & Smilacaceae & Smilax sp. (bana') \\
\hline 35. & Sterculiaceae & Sterculia sp.1, Sterculia sp.2 (sime’), Sterculia sp.3, Sterculia sp.4 (kuerempang) \\
\hline 36. & Taccaceae & Tacca sp. \\
\hline 37. & Theaceae & Theaceae \\
\hline 38. & Tiliaceae & Tiliaceae (gose-gose) \\
\hline 39. & Verbenaceae & Vitex sp. \\
\hline 40. & Zingiberaceae & Ammomum sp. (kacimpang) \\
\hline
\end{tabular}

\section{ACKNOWLEDGMENTS}

We would like to express our gratitude to the Research Centre for Plant Conservation and Botanic Garden-LIPI (Bogor Botanic Garden, West Java), Purwodadi Botanic Garden-LIPI (East Java), South Sulawesi Provincial Government, Forest Management Unit (KPH) Ajatappareng, Forestry Service (South Sulawesi), Pucak Botanic Garden (South Sulawesi), Indonesian Army Special Forces, Gadjah Mada University, The Flora Fauna Research Group of Sub Korwil VII/Gowa-Ekspedisi NKRI Koridor Sulawesi, Mr. Ruspandi for identification and all people who kindly helped and contributed in the expedition.

\section{REFERENCES}

Bouman, R.W., Kesler, P.J.A., \& van Welzen, P. 2019. Lectotypification and amended description of Phyllanthus (Phyllanthaceae) species described by Koorders from Sulawesi, Indonesia. Reinwardtia 18(2):97-103

Cox, P.A. \& Sacks, O.W. 2002. Cycad neurotoxins, consumption of flying foxes, and ALS-PDC disease in Guam. Medical Hypothesis. AAN Enterprises Inc.

Dinas Kehutanan Kabupaten Barru. 2005. Rencana Pembangunan Jangka Panjang Kabupaten Barru. Dinas Kehutanan Kabupaten Barru.

Gradstein S.R., Kessler M., Pitopang R. 2007. Tree species diversity relative to human land uses in tropical rain forest margins in Central Sulawesi. In: Tscharntke T., Leuschner C., Zeller M., Guhardja E., Bidin A. (eds) Stability of Tropical Rainforest Margins. Environmental Science and Engineering (Environmental Science). Springer, Berlin, Heidelberg
Govaerts, R. (ed.). 2000. In: Species 2000 \& IT IS Catalogue of Life, [2020-01-10] Beta (Roskov, Y; Ower, G; Orrel, T.; Nicolson, D.; Bailly, N.; Kirk, P.M.; Bourgoin, T.; DeWalt, R.E.; Decock, W.; Nieukerken, E. van; Penev, L; eds.). Digital resource at www.catalogueoflife.org/col. Species 2000: Naturalis, Leiden, the Netherlands. ISSN 2405-8858

Hill, K.D. 2010. Cycas rumphii. The IUCN Red List of Threatened Species 2010: e.T42081A10623127. https:// dx.doi.org/10.2305/IUCN.UK.2010 3.RLTS.T42081A10623127.en.

Irudayaraj, V. 2011. Opbioglossum reticulatum. The IUCN Red List of Threatened Species 2011: e.T194160A8885705. https:// dx.doi.org/10.2305/IUCN.UK.2011 1.RLTS.T194160A8885705.en. Downloaded on 03 February 2020.

Kikuchi, T., Kadota, S., Hanagaki, S., Suehara, H., Namba, T, Lin, C, \& K. W. 1981. Studies on the Constituents of Orchidaceous Plants. I. Constituents of Nervilia purpurea Schlechter and Nervilia aragoana Gaud. Chem. Pharm. Bull. 29(7):2073-3078

Klein, G., Kim, J., Himmeldirk, K., Cao, Y., \& Chen, X. 2007. Antidiabetes and Anti-obesity Activity of Lagerstroemia speciosa. eCAM 20074 (4): 401-407

Kumoro, A.C., Retnowati, D.S. \& Budiyati, C.S. 2011. Removal of cyanides from gadung (Dioscorea hispida Dennst.) tuber chips using leaching and steaming techniques. J.of App. Sci. Research 7(12):2140-2146

Mamoon, S.A., \& Azam, M.G. 2012. Preliminary phytochemical screening and antidiarrhoeal activity of Derris trifoliata Lour. Int. J. of Phar. Sci. 3(1): 97-100 
Mogea, J., Seibert, B., \& Smits, W. 1991. Multipurpose palms: the sugar palm (Arenga pinnata (Wurmb) Merr.). Agroforestry Systems 13:111-129

Mukherjee, A., Das, R., Pal, A., \& Paul, A.K. 2017. Antibacterial activity of endophytic Bacillus safensis isolated from Ophioglossum reticulatum L. Micr. Res. Journ. Int. 18(5): 1-12

Muliyah, E., Sulistijorini, Sulistiyaningsih, Y.C., Rafi, M. 2017. Tetracera scandens as a medicinal plant: Secretory structures, histochemistry, and antibacterial activity. The Jour. Of Trop. Life. Sci. 8(1): 68-74

Paknia, O., Rajaei Sh., H \& Koch, A. 2015. Lack of well-maintained natural history collections and taxonomists in megadiverse developing countries hampers global biodiversity exploration. Org Divers Evol. 15:619-629. https://doi-org.elibrary.jcu.edu.au/10.1007/ s13127-015-0202-1

Pemerintah Kabupaten Barru. 2013. Rencana Program Investasi Infrastruktur Jangka Menengah (RPI2JM) Kabupaten Barru. Barru.

Riswan, S. 2002. Kajian Biologi Eboni (Diospyros celebica Bakh.). Berita Biologi 6(2): 211-218

Roskov, Y., Zarucchi, J, Novoselova, M \& Bisby, F. (eds.) 2020. ILDIS: ILDIS World Database of Legumes (version 12, May 2014). In: Species 2000 \& IT IS Catalogue of Life, 2020-02-24 (Roskov, Y., Ower, G., Orrel, T, Nicolson, D, Bailly, N., Kirk, P.M., Bourgouin, T., DeWalt, R.E., Decock, W., Nieukerken, E. van, Penev, L.). Digital resource at www.catalogueoflife.org/col. Species 2000: Naturalis, Leiden, the Netherlands. ISSN 2405-8858
Saiful, A.M. \& Burhan, B. 2017. Lukisan fauna, pola sebaran dan lanskap budaya di kawasan kars Sulawesi bagian Selatan. Jurnal Walennae 15 (2): 75-88

Semiarti, E. 2002. Biotechnology for Indonesian orchid conservation and industry. Proc. Of Inventing Prosperous Future through Biological Research and Tropical Biodiversity Management. AIP. Conf. https:// doi.org/10.1063/1.5050118

Thanh, T.B., Thanh, H.N., Minh, P.T., Le-Thi-Thu, H., Ly, H.D.T., \& Duc, L.V. 2015. Protective effect of Tetracera scandens L. leaf extract against $\mathrm{CCI}_{4}$-induced acute liver injury in rats. Asian Pac. J. Trop. Biomed 5(3): 221-227

Walujo, E.B. 2002. Gatra Etnobotani Eboni (Diospyros celebica Bakh.). Berita Biologi 6(2): 251-254

Wenjie, J., Yuchun, F., Chunji, G., Yunhui, W., \& Jie, P. 2009. Extraction and purification of deguelin from Derris trifoliata Lour. root. Int. J. Agric. \& Biol. Eng. 2(4): 98-103

Widjaja, E. \& Pratama, B. 2013. Flora Diversity Loss in Bioregion Sulawesi. Proceeding. International Conference on Forest and Biodiversity. Manado Forestry Research Institute.

World Conservation Monitoring Centre. 1997. Conservation and Management of Trees. Report of Regional Workshop. The Army Hotel, Hanoi, Vietnam.

World Conservation Monitoring Centre. 1998. Diospyros celebica. The IUCN Red List of Threatened Species 1998. e.T33203A9765120. https:/ / dx.doi.org/10.2305/IUCN.UK. 1998.RLTS.T33203A9765120.en. 